\title{
EPIDERMAL MICRO-MORPHOLOGICAL STUDY ON STEMS OF MEMBERS OF THE FAMILY CHENOPODIACEAE
}

\author{
El GHAZALI, G. E. B. $.^{{ }^{*}}-$ Al SOQEeR, A. ${ }^{2}-$ ABDALlA, W. E. ${ }^{1}$ \\ ${ }^{1}$ Faculty of Science and Arts at Al Rass, Qassim University, Saudi Arabia \\ (fax: +9661633351600$)$ \\ ${ }^{2}$ Faculty of Agriculture and Veterinary Medicine, Qassim University, Saudi Arabia \\ *Corresponding author \\ e-mail: gamalelghazali@gmail.com \\ (phone+966502492660) \\ (Received 25 $5^{\text {th }}$ May 2016; accepted 25 th $^{\text {Aug 2016) }}$
}

\begin{abstract}
Stems of 14 species belonging to 10 genera of the family Chenopodiaceae were examined under scanning electron microscope (SEM). Micro-morphological characters such as sculpture of epicuticular wax, trichomes and surface relief were investigated. These characters were clumped into five groups. These groups do not coincide solely with the five tribes of the species studied. The study presented epicuticular wax sculptures and surface reliefs not previously reported for the family Chenopodiaceae.
\end{abstract}

Keywords: scanning electron microscope, epicuticular wax sculpture, trichome, surface relief, semi-arid

\section{Introduction}

Epidermal characters as revealed by scanning electron microscopes (SEM) exhibit a variety of micro-morphological features (Barthlott, 1990), influenced by the environment (Sattler and Rutishauser, 1997; Koch and Ensikat, 2008), and act as a barrier against mechanical damages, insects, excessive light and loss of water (Bird and Gray, 2003; Rudall, 2007; Mauseth, 2008). These epidermal characters can reflect the relationships between habitat and phytogenetics of the plants (Liu, 2006).

Chenopodiaceae Vent., commonly known as Goosefoot family, is cosmopolitan, especially diverse in arid, semi-arid, saline and hypersaline ecosystems (Kuhn et al., 1993; Hedge et al., 1997). Members of the family Chenopodiaceae are represented in the flora of Saudi Arabia by 74 species belonging to 23 genera which grow in many regions (Chaudhary, 1999), with Qassim Region accommodating a considerable number (Al-Turki, 1997).

Epidermal characters of leaves, flowers, fruits and seeds of various species of the Chenopodiaceae were previously studied using (SEM) (Poompozhil and Kumarasamy, 2014; Sukhorukov, 2012; Toderich et al., 2012; Fuente et al., 2011; Akhani et al., 2005; Karcz et al., 2005; Klopper and Van Wyk, 2001). However, epidermal studies on stems and branches of members of the Chenopodiaceae using SEM are scarce and hardly encountered.

Stems and branches of the family might be jointed (articulated), succulent, grooved, striped, striated and often ridged or angled (Freitag et al., 2009; Keshavarzi and Zare, 2006; Ke et al., 2003; Chaudhary, 1999).

These Chenopodiaceous stem characters show a great plasticity and variability according to the environmental conditions, and exhibits distinct structural adaptations (Kuhn et al., 1993). The primary objective of the present study is to investigate 
epidermal micro-morphological characters of stems of various members of the family Chenopodiaceae using SEM, in an attempt to understand their structural characteristics and to evaluate their taxonomic significance.

\section{Materials and methods}

\section{Study area}

Qassim Region (Saudi Arabia), occupies the northern centre of the Arabia Peninsula. It is situated between latitude $24^{\circ} 30^{\prime}-27^{\circ} 15^{\prime}$ north and longitude $41^{\circ} 30^{\prime}-45^{\circ} 41^{\prime}$ east, and is bounded by Hail Region in the north and northwest, Al Madina Region in the west, and Riyadh Region in the south and east (map 1). The area is an exposed complex of Precambrian igneous and metamorphic rocks and part of the large belt of phanerozoic formations that overlap the northern and eastern edge of the Arabia shield which consists of escarpments composed of Paleozoic to Mesozoic sandstone and limestone (Al-Turki, 1997). The climate of the Qassim Region is characterized by very hot dry summers and mild to cool winters (Abd El-Rahman, 1986).

\section{Vegetation}

According to White and Leonard (1991), Qassim Region falls within the SaharoArabian Region whereby the plant species are usually adapted to aridity and very high temperature. The vegetation cover is mainly concentrated in depressions, wadis and ravines where water usually accumulated, over stable sand dunes and short sheets (Al Nafie, 2008).

\section{Plant Material}

Stems from 14 species belonging to the family Chenopodiaceae were collected fresh from Qassim Region, Saudi Arabia. According to Kadereit et al. (2003, 2005), these species belong to 10 genera, 5 tribes and 3 subfamilies. These species are: Chenopodium ambrosioides L., C. murale L. (Tribe: Chenopodieae, Subfamily: Chenopodioideae), Atriplex leucoclada Boiss. (Tribe: Atripliceae, Subfamily: Chenopodioideae), Suaeda vermiculata Forssk. ex J.F. Gmelin (Tribe: Suaedeae, Subfamily: Suaedaoideae), Bassia muricata (L.) Asch. (Tribe: Camphorosmeae, Subfamily: Salsoloideae), Anabasis setifera Moq., Cornulaca monacantha Del., Halothamnus iraqensis Botsch., Haloxylon persicum Bunge ex Boiss., H. salicornicum (Moq.) Bunge ex Boiss., Salsola arabica Botsch., S. drummondii Ulb., S. imbricata Forssk., Seidlitzia rosmarinus Bunge ex Boiss. (Tribe: Salsoleae, Subfamily: Salsoloideae).

The fresh plant material collected, were air-dried at room temperature prior to analysis. For consistency, undamaged stem portions were selected from an area midway of lateral branches.

\section{Preparation of Plants for SEM}

Stem portions (approximately $5 \mathrm{~mm}$ long) were mounted on Aluminum stubs with double-coated carbon conductive tape, coated with Platinum by (JEOL JFC - 1300) sputter, and observed with (JEOL JSM 5500) scanning electron microscope (SEM). The herbarium specimens and photomicrographs were deposited at Al Rass College of 
Science and Arts, College of Applied Medical Science, Qassim University, and King Saud University Herbarium (KSU), Saudi Arabia. The terminology of epicuticular wax follows Barthlott et al. (1998) and for trichomes it follows Toderich et al. (2010).

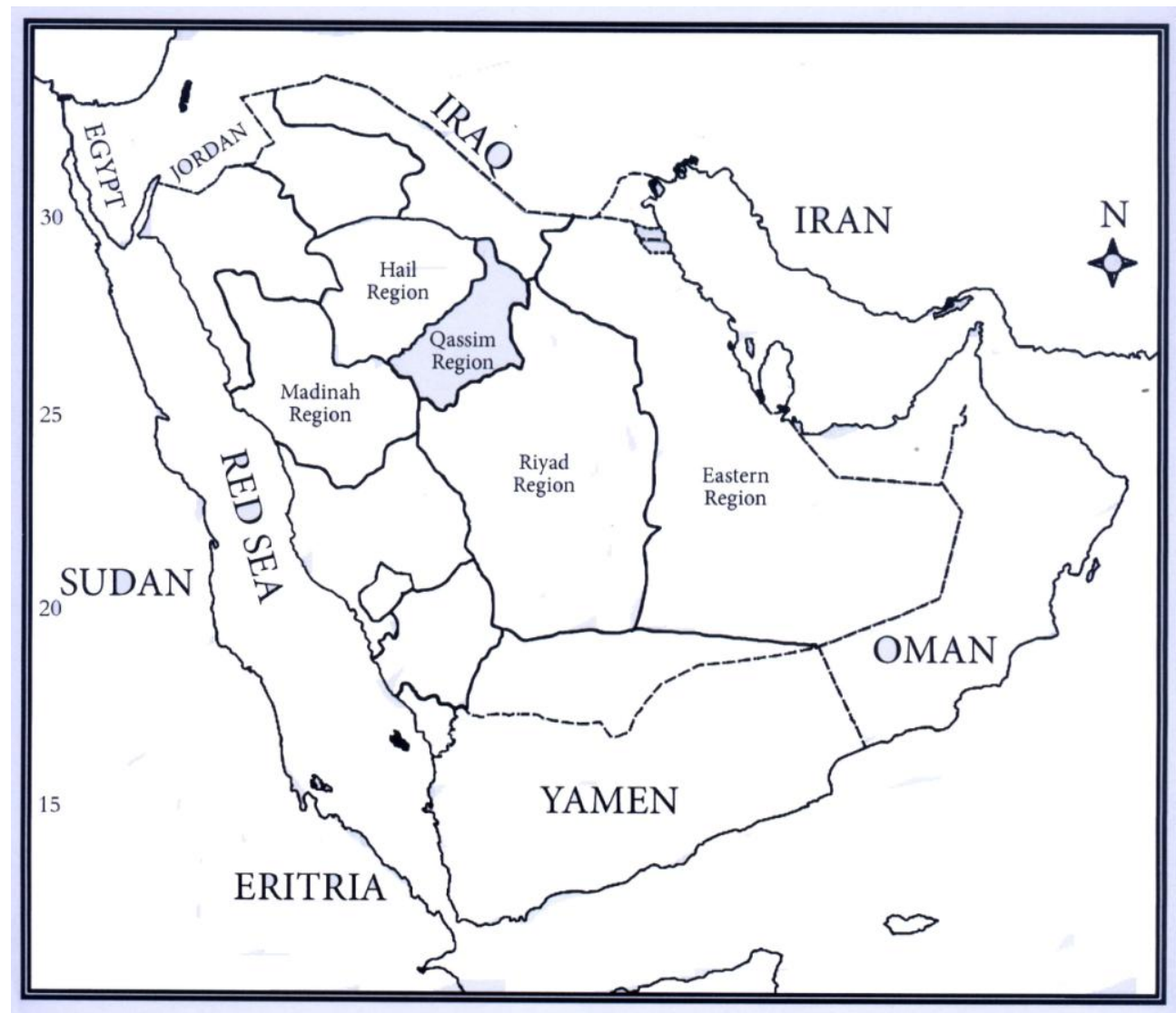

Map 1. Location of Qassim Region, Saudi Arabia

\section{Results}

Stems from 14 species belonging to 10 genera of the family Chenopodiaceae were examined under scanning electron microscope (SEM). These stems showed a considerable variation with respect to epidermal micro-morphological structures. According to these epidermal structures, five main groups of species can be recognized within the species investigated, as shown in table (1) and figures (1-3).

Table 1. Epidermal micro-morphological structures of stems of members from Chenopodiaceae

\begin{tabular}{|c|c|c|c|c|}
\hline $\begin{array}{l}\text { Group } \\
\text { number }\end{array}$ & Epidermal character & Species & Tribe & Subfamily \\
\hline \multirow{3}{*}{ Group I } & $\begin{array}{l}\text { Stems with glandular } \\
\text { trichomes: }\end{array}$ & & & \\
\hline & $\begin{array}{l}\text { - with collapsed salt } \\
\text { bladders }\end{array}$ & $\begin{array}{l}\text { Atriplex leucoclada (Fig. 1: } \\
\text { A-B) }\end{array}$ & Atripliceae & Chenopodioideae \\
\hline & - with papillae & $\begin{array}{l}\text { Salsola drummondii (Fig. 1: } \\
\text { C) }\end{array}$ & Salsoleae & Salsoloideae \\
\hline
\end{tabular}




\begin{tabular}{|c|c|c|c|c|}
\hline $\begin{array}{l}\text { Group } \\
\text { number }\end{array}$ & Epidermal character & Species & Tribe & Subfamily \\
\hline \multirow{5}{*}{ Group II } & $\begin{array}{l}\text { Stems with non- } \\
\text { glandular trichomes: }\end{array}$ & & & \\
\hline & $\begin{array}{l}\text { - with sparse short } \\
\text { unbranched } \\
\text { trichomes } \\
\end{array}$ & $\begin{array}{l}\text { Salsola imbricata (Fig. 1: } \\
\text { D) }\end{array}$ & Salsoleae & \multirow{4}{*}{ Salsoloideae } \\
\hline & \multirow{3}{*}{$\begin{array}{l}\text { - with dense } \\
\text { unbranched } \\
\text { elongated } \\
\text { trichomes }\end{array}$} & $\begin{array}{l}\text { Bassia muricata (Fig. 1: E- } \\
\text { F) }\end{array}$ & Camphorosmeae & \\
\hline & & $\begin{array}{l}\text { Cornulaca monacantha } \\
\text { (Fig. 2: } A-B)\end{array}$ & \multirow{2}{*}{ Salsoleae } & \\
\hline & & $\begin{array}{l}\text { Salsola arabica (Fig. 2: } C \text { - } \\
\text { D) }\end{array}$ & & \\
\hline Group III & $\begin{array}{l}\text { Stems relief with } \\
\text { rugulate crusts of } \\
\text { epicuticular wax }\end{array}$ & $\begin{array}{l}\text { Haloxylon persicum (Fig. 3: } \\
\text { A) }\end{array}$ & Salsoleae & Salsoloideae \\
\hline \multirow{5}{*}{ Group IV } & \multirow{5}{*}{$\begin{array}{l}\text { Stems relief striate with } \\
\text { crusts of epicuticular } \\
\text { wax }\end{array}$} & Anabasis setifera (Fig. 3: D) & \multirow{4}{*}{ Salsoleae } & \multirow{4}{*}{ Salsoloideae } \\
\hline & & $\begin{array}{l}\text { Halothamnus iraqensis (Fig. } \\
\text { 3: E) }\end{array}$ & & \\
\hline & & $\begin{array}{l}\text { Haloxylon salicornicum } \\
(\text { Fig. 3: B) }\end{array}$ & & \\
\hline & & $\begin{array}{l}\text { Seidlitzia rosmarinus (Fig. } \\
3: F)\end{array}$ & & \\
\hline & & $\begin{array}{l}\text { Suaeda vermiculata (Fig. 3: } \\
\text { C) }\end{array}$ & Suaedeae & Suaedaoideae \\
\hline \multirow{2}{*}{ Group V } & \multirow{2}{*}{$\begin{array}{l}\text { Stems with parallel } \\
\text { longitudinal ridges and } \\
\text { grooves } 10-20 \mu \mathrm{m} \text { in } \\
\text { width }\end{array}$} & $\begin{array}{l}\text { Chenopodium ambrosioides } \\
\text { (Fig. } 2: \text { E) }\end{array}$ & \multirow{2}{*}{ Chenopodieae } & \multirow{2}{*}{ Chenopodioideae } \\
\hline & & C. murale (Fig. 2: F) & & \\
\hline
\end{tabular}




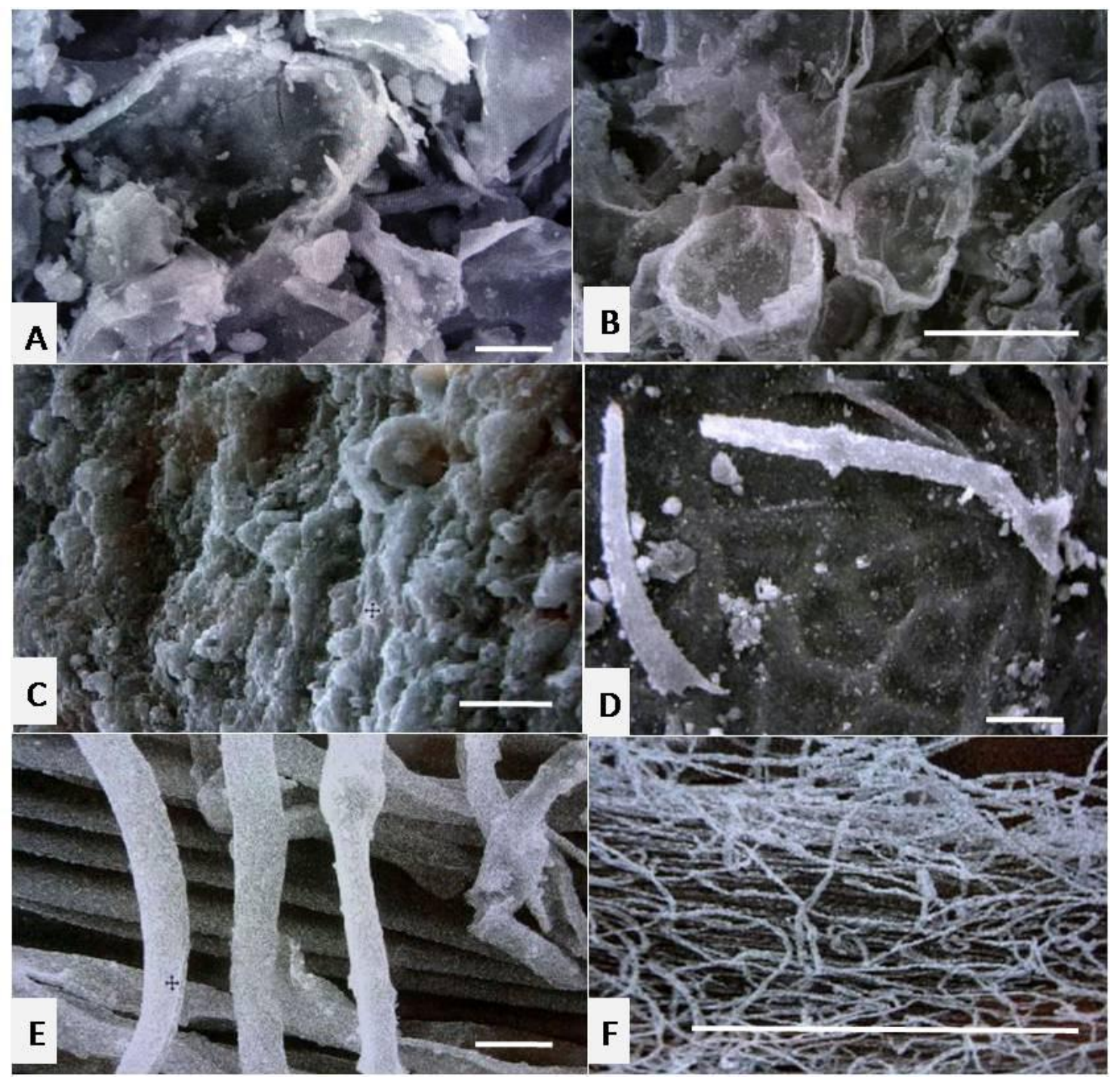

Figure 1. Scanning electron micrographs of epidermal characters on stems:

A-B: Atriplex leucoclada X 1000 \& 500 respectively, with collapsed salt bladders. $\boldsymbol{C}$ : Salsola drummondii X 1000, with papillate trichomes. D: S. imbricata X 1000, with sparse short unbranched trichomes and reticulate surface relief. E-F: Bassia muricata X 1000 \& 100 respectively, with dense unbranched trichomes. Scale bar $=20 \mu \mathrm{m}$. 


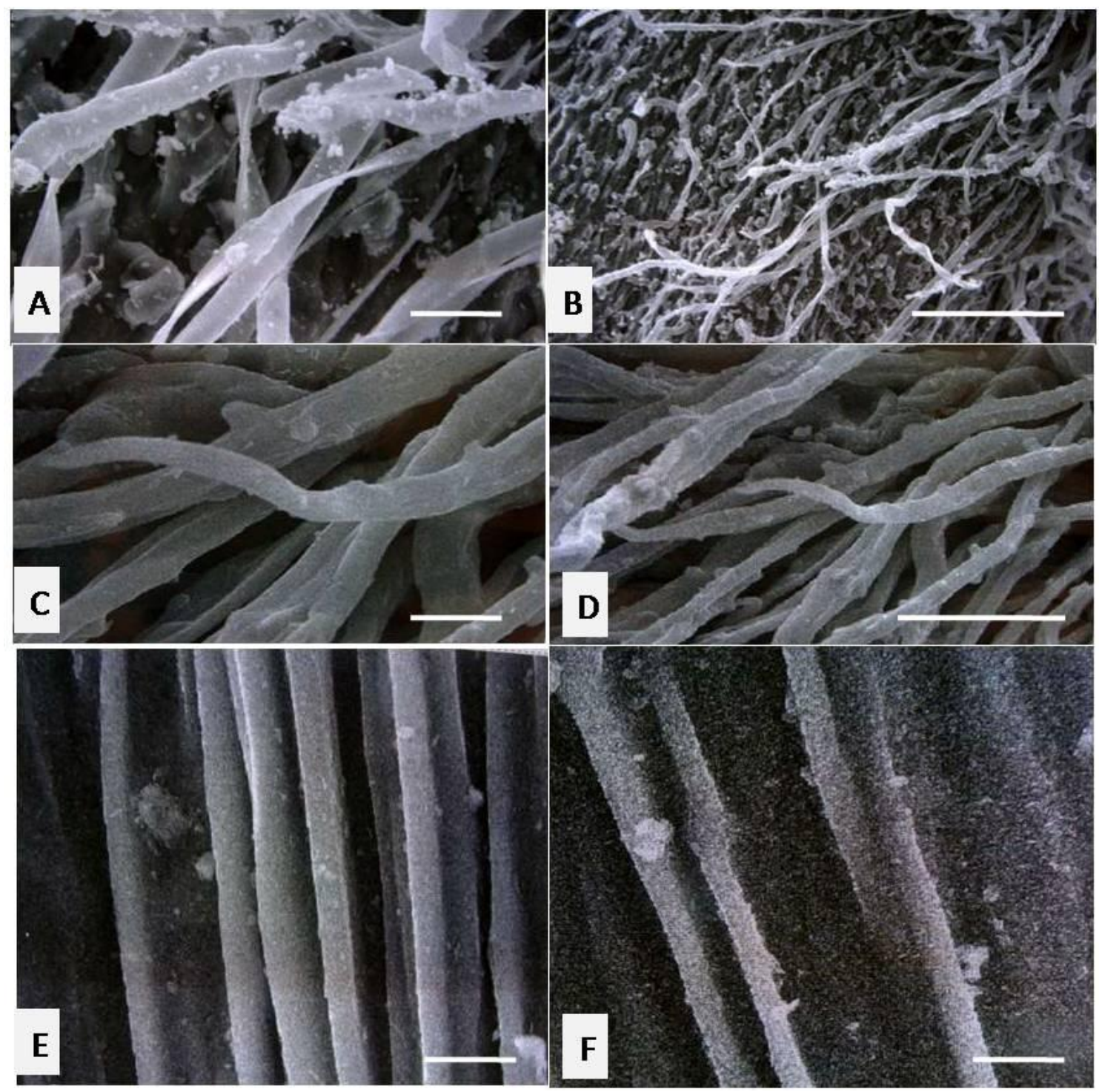

Figure 2. Scanning electron micrographs of epidermal characters on stems:

A-B: Cornulaca monacantha $X 1000$ and 500 respectively, with elongated unbranched trichomes and verrucate surface relief. $\boldsymbol{C}$-D: Salsola arabica $X 1000$ and X500 respectively, with elongated unbrached trichomes. $\boldsymbol{E}$ : Chenopodium ambrosioides X 1000, and $\boldsymbol{F}: C$. murale X 1000, with parallel longitudinal ridges. Scale bar $=20 \mu \mathrm{m}$. 

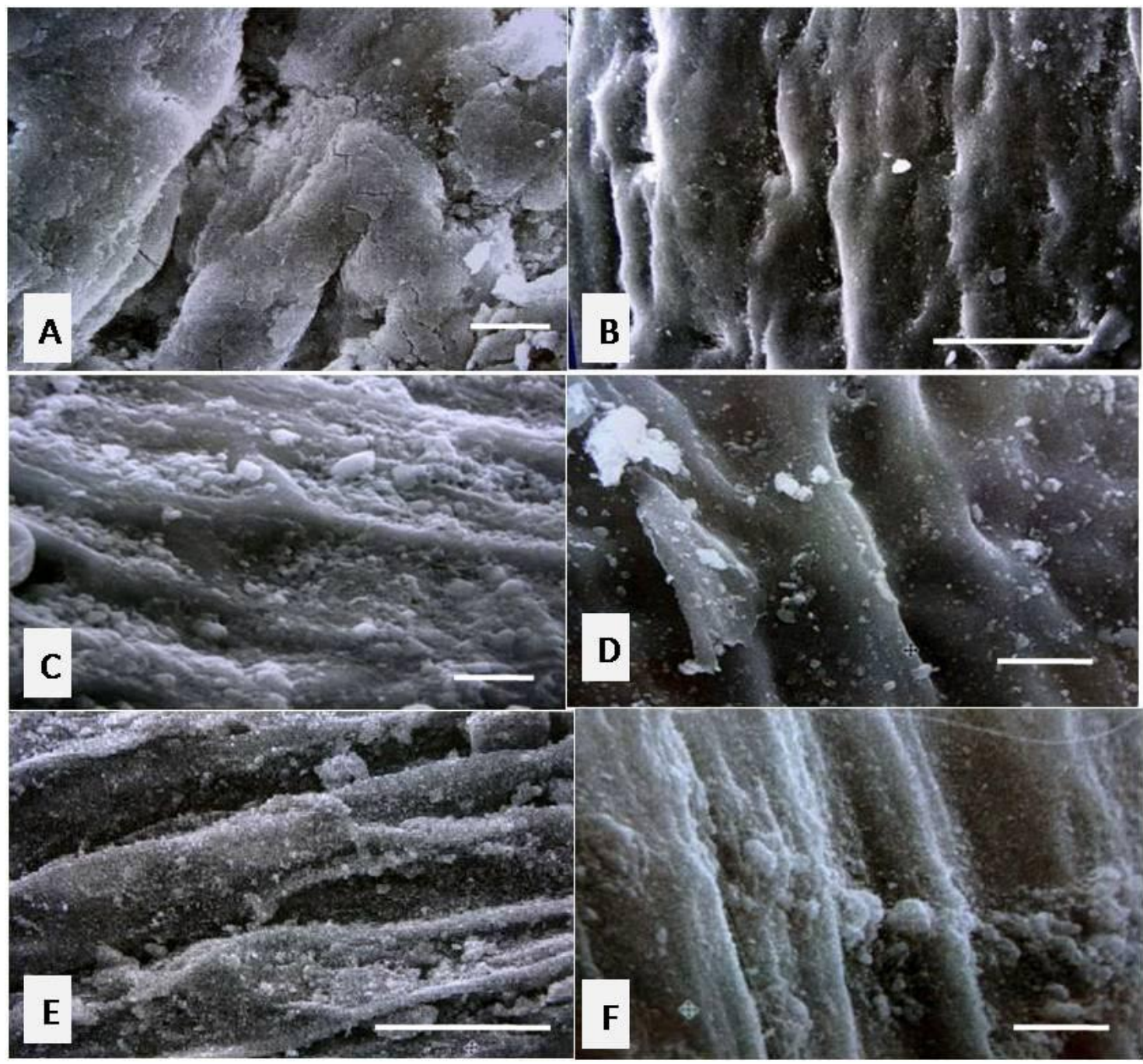

Figure 3. Scanning electron micrographs of epidermal characters on stems:

A: Haloxylon persicum X 1000, with rugulate crusts. B: H: salicornicum X 500, C: Suaeda vermiculata X 1000, D: Anabasis setifera X 1000, E: Halothamnus iraqensis X 500, F: Seidlitzia rosmarinus $X$ 1000, with striate crusts. Scale bar $=20 \mu \mathrm{m}$.

\section{Discussion}

The results showed that group (II), (III) and (V), each is characteristic for a specific subfamily, while groups (I) and (IV), each is present in two subfamilies (table 1). The same findings apply to tribes, with the exception that the subfamily in group (II) is further divided into two tribes. Thus, these five groups do not coincide solely with the five tribes in the present study, however, it might coincide partly with the three subfamilies.

The genus Salsola (represented by three species), is the most diverse, being represented in three groups, whereas the micro-morphological characteristics of the genera Chenopodium and Atriplex (both belonging to subfamily Chenopodioideae) are diagnostic for specific groups. Members of group (IV) possess succulent stems and are characterized by the presence of striate crusts of epicuticular wax. 
Chenopods have evolved numerous morphological strategies for adaptation to grow under harsh conditions of aridity and salinity.

Epidermal micro-morphological characteristics of the stems of 14 species belonging to 10 genera of the Chenopodiaceae as revealed by SEM, showed various adaptations to face the adverse environmental conditions present at the semi-arid Qassim Region, Saudi Arabia. These epidermal micro-morphological characteristics were clumped in the present study into five groups. These groups were mainly identified based on sculpture of epicuticular wax, presence of trichomes and the relief of the surface. These groups showed that various species responded differently to environmental stresses.

Chenopodium ambrosioides and $C$. murale were reported in the present study to exhibit distinctive surface relief represented by parallel longitudinal ridges and grooves. Karcz et al. (2005) reported reticulate, flatly tuberculate, and smooth and finely lineated topography on the surface of fruits and seeds of three Chenopodium species. Engel and Barthlott (1988) reported radial orientation of platelets on the leaves of C. giganteum, whereas $\mathrm{Lu}$ et al. (2012) reported the presence of salt bladders on the leaves of $C$. album. No previous detailed studies on the stems surface micro-morphological structures were encountered in the literature.

Trichomes are appendages from the epidermis including glandular and non-glandular hairs, scales and papillae (Toderich et al., 2010). According to Werker (2000), appendages are considered trichomes when they include both cell wall and lumen, and their height reaches above a certain critical size, to distinguish them from other micromorphological characters. According to Toderich et al. (2010) terminology, four types of trichomes (two glandular and two non-glandular) were reported in the species examined. Members of the genus Salsola studied, constitute three out of these four glandular types of trichomes.

This diversity in trichomes may be attributed to the extremely variable ecomorphology of the genus Salsola (Akhani et al., 2007). These trichomes play a significant taxonomic importance in the current intra-familiar classification of the family Chenopodiaceae (Carolin, 1983). Atriplex leucoclada is the only species reported in this study to possess salt bladders. These salt bladders are also characteristic of Oxalidaceae and Mesembryanthemaceae (Shabala and Munns, 2012; Agarie et al., 2007). Within the Chenopodiaceae, salt bladders occur in all species of the genera Atriplex, Obione and Halimione, and in some species of the genera Salsola and Chenopodium (Batanouny, 2001). Salt glands, on the other hand, are anatomically distinct from salt bladders and occur in several families e.g. Plumbaginaceae, Aviceniaceae, Tamaricaceae, Frankeniceae, Poaceae etc. (Liphschschitz and Waisel, 1982; Tan et al., 2013; Balsamo and Thomson, 1993). Salt bladders secrete excess salt and contribute to salt balance (Agarie et al., 2007), reduce transpiration by increasing surface reflectance (Freitas and Breckle, 1992) and deter insect herbivores (LoPresti, 2013).

According to Barthlott et al. (1998) terminology, epicuticular wax crusts with various ornamentations were encountered in the present study. However, Engel and Barthlott (1988) on their study on limited number of taxa in the Chenopodiaceae, observed platelets of various shapes and orientations on the leaves instead. The current study presented epicuticular wax sculpture on the stems not previously encountered as characteristic of the family Chenopodiaceae. Patterns and morphology of these plant waxes were used in plant systematics of various taxa (El Ghazali, 2008; Ditsch and Barthlott, 1997; Henning et al., 1994; Frohlich and Barthlott, 1988). 
Jetter and Riederer (1994) showed that under varying environmental conditions, the epicuticular wax can be deposited into different morphological shapes. The latter study suggested that more studies should be undertaken on the epicuticular wax deposits of the Chenopodiaceae in different habitats, parts of the plants organ (leaves, stems, fruits, etc.), seasons, and different stages of development, in an attempt to have the overall range of variations in the wax deposits of the family.

Acknowledgements. The authors gratefully acknowledge the generous financial support provided by the Deanship of Scientific Research, Qassim University, to Said Osman for technical assistance in preparing the SEM micrographs, and to Faculty of Applied Medical Science, Qassim University, for various help received.

\section{REFERENCES}

[1] Abd El-Rahman, A.A. (1986). The desert of the Arabian Peninsula. -In: Evanar, M., Noy-Meir, I., Goodall, D.W. (eds.) Deserts and Arid Shrublands, Ecosystems of the World, 12 (B): 29-55. Elsevier Pub.: Amsterdam.

[2] Agarie, S., Shimoda, T., Shimizu, Y., Baumann, K., Sunagawa, H., Kondo, A., Ueno, O., Nakahara, T., Nose, A., Cushman, J.C. (2007): Salt tolerance, salt accumulation, and ionic homeostasis in an epidermal bladder-cell-less mutant of the common ice plant Mesembryanthemum crystallinum. - Journal of Experimental Botany 58: 1957.

[3] Al-Nafie, A.H. (2008). Phytogeography of Saudi Arabi. - Saudi Journal of Biological Sciences 15(1): 159-176.

[4] Al-Turki, T.A. (1997): A preliminary checklist of the flora of Qassim, Saudi Arabia. Feddes Repertorium 108 (3-4): 259-280.

[5] Akhani, H., Barroca, J., Koteeva, N., Voznesnskaya, E., Franceschi, V., Edwards, G., Ghaffari, S.M., Ziegler, H. (2005): Bienertia sinuspersici (Chenopodiaceae): A new species from southwest Asia and discovery of a third terrestrial C4 plant without Kranz anatomy. - Systematic Botany 30 (2): 290-301.

[6] Akhani, H., Edwards, G.H., Roalson, E.H. (2007): Diversification of the old world Salsoleae s. 1. (Chenopodiaceae): molecular phylogenetic analysis of nuclear and chloroplast data sets and a revised classification. - Int. J. Plant Sci. 168 (6): 931-956.

[7] Balsamo, R.A., Thomas, W.W. (1993): Ultrastructural features associated with secretion in the salt glands of Frankenia grandifolia (Frankeniaceae) and Avicennia germinans (Avicenniaceae). - American Journal of Botany 80 (11): 1276-1283.

[8] Batanouny, K.H. (2001): Adaptation of plants to saline conditions in Arid Regions. - In: Cloudsley-Thompson, J.L. (ed.) Adaptations of desert organisms: Plants in the deserts of the Middle East. pp. 145-166. Springer-Verlag: Berlin, Heidelberb.

[9] Barthlott, W. (1990): Scanning electron microscopy of the epidermal surface in plants. In: Claugher, D. (ed.) Scanning electron microscopy in taxonomy and functional morphology, pp. 69-94. Clarendon Press: Oxford.

[10] Barthlott ,W., Neinhuis, C., Cutler, D., Ditsch, F., Meusel, I., Theisen, I., Wilhelmi, H. (1998): Classification and terminology of plant epicuticular waxes. - Bot. J. of the Linnean Soc. 126: 237-206.

[11] Bird, S.M., Gray, J.E. (2003): Signals from the cuticle affect epidermal cell differentiation. - New Phytologist 157: 9-23.

[12] Carolin, R.C. (1983): The trichomes of the Chenopodiaceae and the Amaranthaceae. Bot. Jb. Syst. 103: 451-466.

[13] Chaudhary, S.A. (1999): Flora of the Kingdom of Saudi Arabia, Volume One. Ministry of Agriculture and Water: Riyad, Kingdom of Saudi Arabia. 
[14] Ditsch, F., Barthlott, W. (1997): Mikromorphologie der Epicuticularwachse und das System der Dilleniidae und Rosidae. - Trop. subtrop. Pflanzenwelt 97:1-248.

[15] El Ghazali, G.E.B. (2008): A study on the epicuticular wax morphology of African Acacias. - J. King Saud University 20 (2): 101-111.

[16] Engel, T., Barthlott, W. (1988): Micromorphology of epicuticular waxes in Centrosperms. - Plant Systematics and Evolution 161: 71-85.

[17] Frölich, D., Barthlott, W. (1988): Die Mikromorphologie der epicuticularen Wachse und das System der Monocotylen. - Trop. subtrop. Pflanzenwelt 63:279-409.

[18] Freitag, H., Atamov, V., Celin, E., Aslan, M. (2009): The genus Halothamnus Jaub. \& Spach. (Chenopodiaceae) in Turkey. - Turk. J. Bot. 33: 325-334.

[19] Freitas, H., Breckle, S.W. (1992): Importance of bladder hairs for salt tolerance of field grown Atriplex species from a Portuguese salt march. - Flora 187:283-297.

[20] Fuente, V., Nieto, L.R., Sanchez-Mata, D. (2011): Sarcocornia hispanica (Chenopodiaceae), a new species from the Iberian Peninsula. - Lazarov 32: 9-13.

[21] Hedge, I.C., Akhani, H., Freitag, H., Kothe-Heinrich, G., Podlech, D., Rilke, S., Uotila, P. (1997): Chenopodiaceae. - In: Rechinger, K.H. (ed.) Flora Iranica, pp. 1-371. Akademische Druck und Verlagsanstalt: Graz, Austria.

[22] Hennig, S., Barthlott, W., Meusel, I., Theisen, I. (1994): Mikromorphologie der Epicuticularwachse und die Systematik der Hamamelididae, Magnoliidae und Ranunculidae. - Trop. subtrop. Pflanzenwelt 90: 5-60.

[23] Jetter, R., Riederer, M. (1994): Epicuticular crystals of nonacosan-10-ol: In-vitro reconstitution and factors influencing crystal habits. - Planta, 195 (2): 257-270.

[24] Kadereit, G., Borsch, T., Weising, K., Freitag, H. (2003): Phylogeny of Amaranthaceae and Chenopodiaceae and the evolution of $\mathrm{C} 4$ photosynthesis. - International Journal of Plant Science 164: 959-986.

[25] Kadereit, G., Gotzekb, D., Jacobs, S., Freitag, H. (2005): Origin and age of Australian Chenopodiaceae. - Organisms Diversity \& Evolution 5 (1): 59-80.

[26] Karcz, J., Kolano, B., Maluszynska, J. (2005): SEM studies on fruit and seed of some Chenopdium L. species (Chenopodiaceae). 12th International Conference on Plant Embryology: Cracow, Poland.

[27] Ke, L., Gelin, Z., Ge-Ling, C., Mosyakin, S.L., Clements, S.E. (2003): Chenopodiaceae. - Flora of China 5: 351-414.

[28] Keshavarzi, M., Zare, G. (2006): Anatomical study of Salicornieae Dumort (Chenopodiaceae Vent.) native to Iran. - International Journal of Botany 2(3): 278-285.

[29] Klopper, R.R., Van Wyk, A.E. (2001): The genus Salsola (Chenopodiaceae) in South Africa: systematic significance of leaf anatomy. - South African Journal of Botany, 67 (4): 540-551.

[30] Koch, K., Ensikat, H. (2008): The hydrophobic coatings of plant surfaces: Epicuticular wax crystals and their morphologies, crystallinity and molecular self- assembly. - Micron 39 (7): 759-772.

[31] Kuhn, U., Bittrich, V., Carolin, R.C., Freitag, H., Hedge, H., Uotila, P., Wilson, P.G. (1993): Chenopodiaceae. - In: Kubitzki, K., Rohwer, J.G., Bittrich, V. (ed.) The Families and Genera of Vascular Plants, Flowering Plants (Dicotyledons), pp. 253-281. Springer Verlag: Berlin.

[32] Liphschitz, N., Waisel, Y. (1982): Adaptation of plants to saline environments: salt excretion and glandular structure. - In: Sen, D.N., Rajpurohit, K.S. (ed.) Tasks for vegetation science, pp. 197-214. Dr. W. Junk Publisher: The Hague.

[33] LoPresti, E.F. (2013): Chenopod salt bladders deter insect herbivores. - Oecologia, 174 (3): 921-30.

[34] Liu, M. (2006): Morphology and anatomy of seed plant. Science Press: Beijing, China, pp. 121-268.

[35] Lu, X., You, T., Zhao Chen, S., Lan, H. (2012): Morphology and physiological responses of Chenopodium album L. under salt stress. - Plant Physiology Journal 48 (5): 477-484. 
Mauseth, J.D. (2008): Botany: an introduction to plant biology. Jones and Bartlett Pub.: Sudbury.

[36] Poompozhil, S., Kumarasamy, D. (2014): Leaf anatomical studies on some Mangrove plants. - Journal of Academic and Industrial Research, 2 (10): 583.

[37] Rudall, P. (2007): Anatomy of flowering plants, an introduction to structure and development. Cambridge University Press: New York.

[38] Sattler, R., Rutishauser, R. (1997): The fundamental relevance of morphology and morphogenesis to plant research. - Annals Bot. 80 (5): 571-582.

[39] Shabala, S., Munns, R. (2012): Salinity stress: Physiological constraints and adaptive mechanisms. - In: Shabala, S. (ed.) Plant stress physiology, pp. 59-93. CABI publishing: Wallingford, U.K.

[40] Sukhorukov, A.P. (2012): Taxonomic notes on Dysphania and Atriplex (Chenopodiaceae). - Willdenowia 42 (2): 169-180.

[41] Tan, W.K., Lin, Q., Lim, T.M., Kumar, P., Loh, C.S. (2013): Dynamic secretion changes in the salt glands of the mangrove tree species Avicennia officinalia in response to a changing saline environment. - Plant Cell Environ 36 (8): 1410-22.

[42] Toderich, K.N., Shuyskaya, E.V., Taha, F., Ismail, S., Gismatullina, L.G., Li, E.V. (2012): Adaptive fruit structural mechanisms of Asiatic Salsola species and its germplasm conservation and utilization. - Journal of Arid Land Studies 22 (1): 73-76.

[43] Toderich, K.N., Shuyskaya, E.V., Khujanazov, T.M., Ismail, S., Kawabata, Y. (2010): The structural and functional characteristics of Asiatic Desert Halophytes for Phytostabilization of polluted sites. - In: Ashraf, M., Oztuek, M., Ahmad, M.S.A. (eds.) Plant adaptation and phytoremediation, pp. 245-274. Springer Dorgrecht Heiddelberg: London, New York.

[44] Werker, E. (2000): Trichome diversity and development. - In: Hallahan, D.L., Callow, J.C. (ed.) Advances in Botanical Research, incorporating advances in plant pathology: plant trichomes, pp. 1-36. Academic Press: London.

[45] White, F. \& Leonard, J. (1991). Phytogeographical links between Africa and Southwest Asia. - Fl. \& Veg. Mundi 9: 229-246. 